\title{
MICROBIOLOGICAL INVESTIGATIONS ON THE WATER OF A THERMAL BATH AT BUDAPEST
}

\author{
SÁRA SZURÓCZKI, ZsUZSA KÉKI, SZANDRA KÁLI, ANETT LIPPAI, \\ KÁROLY MÁRIALIGETI and ERIKA TÓTH* \\ Department of Microbiology, Eötvös Lorand University, Budapest, Hungary
}

(Received: 19 February 2016; accepted: 14 April 2016)

Thermal baths are unique aquatic environments combining a wide variety of natural and anthropogenic ecological factors, which also appear in their microbiological state. There is limited information on the microbiology of thermal baths in their complexity, tracking community shifts from the thermal wells to the pools. In the present study, the natural microbial community of well and pool waters in Gellért bath was studied in detail by cultivation-based techniques. To isolate bacteria, $10 \% \mathrm{R} 2 \mathrm{~A}$ and minimal synthetic media (with "bath water") with agar-agar and gellan gum were used after prolonged incubation time; moreover, polyurethane blocks covered with media were also applied. Strains were identified by sequencing their 16S rRNA gene after grouping them by amplified rDNA restriction analysis. From each sample, the dominance of Alphaproteobacteria was characteristic though their diversity differed among samples. Members of Actinobacteria, Firmicutes, Beta- and Gammaproteobacteria, Deinococcus-Thermus, and Bacteroidetes were also identified. Representatives of Deinococcus-Thermus phylum appeared only in the pool water. The largest groups in the pool water belonged to the Tistrella and Chelatococcus genera. The most dominant member in the well water was a new taxon, its similarity to Hartmannibacter diazotrophicus as closest relative was $93.93 \%$.

Keywords: cultivation, Gellért bath, well and pool waters, 16S rDNA, bacterial community structure

\section{Introduction}

Hot springs and thermal baths support diverse unique microbial communities. The pools of the thermal baths and spas are loaded with well or spring water. These baths are visited often for medical treatment or just for leisure purposes by many people. At the same time, except the control of the obligatory hygienic and the required chemical parameters, there are only a few investigations on these bath

\footnotetext{
*Corresponding author; E-mail: erika.toth@ttk.elte.hu
} 
waters. Terrestrial hot springs located in Iceland, New Zealand, Japan, the United States (National Park of Yellowstone), Italy (area of Naples), and Russia (Peninsula of Kamchatka) are extensively studied [1].

In Hungary, there have been only a few research studies that studied the complete bacterial diversity of the well and pool waters of thermal baths yet [2-5]. The Gellért bath is located in Budapest (Hungary), where Europe's largest natural flowing water thermal system (Buda Thermal Karst System) is located [6]. The Rác, Gellért, and Rudas spas are supplied by the water of the spring group of Gellért Hill via drilled wells [4]. The well water is characterized by high $\mathrm{Ca}^{2+}, \mathrm{Mg}^{2+}, \mathrm{HCO}_{3}{ }^{-}$, and $\mathrm{SO}_{4}{ }^{2-}$ [7]. The chemical parameters of the well water are controlled by the laboratory of Gellért bath (http://www.gellertfurdo.hu/viz-osszetetele)

The water of the well contains only limited organic carbon source, however, oligotrophic bacteria due to their metabolic flexibility are able to thrive under very low nutrient condition [8]. To cultivate oligotrophic microorganisms under laboratory conditions is still a challenge. It is estimated that less than $1 \%$ of bacteria can be cultivated in laboratory conditions [9]. There has been a focus in recent years on developing methods for the in vitro cultivation of those bacteria so far remained uncultured. In previous studies, increased incubation time [10], use of alternative gelling agent [11], in situ cultivation on media-supplemented polyurethane foam [12], or developed new media [13] were successfully used to cultivate uncultured microbes.

The aim of the present study was to reveal the cultivable bacterial communities of the well and pool waters of the Gellért bath using classical and special cultivation techniques.

\section{Materials and Methods}

\section{Sampling}

Sampling was carried out on 28.10.2013 from water that drains directly to the men's pool (originating from the well) and the men's pool water of Gellért bath, Budapest, Hungary. The temperature of the well water was $47^{\circ} \mathrm{C}$ though at the sampling point water temperature was only $36{ }^{\circ} \mathrm{C}$ and the $\mathrm{pH}$ was 7.5 . The well water flows without any treatment to the swimming pool. The pool water was $36^{\circ} \mathrm{C}$ and the $\mathrm{pH}$ was 7.0 . The thermal water is continuously flowing into the pool, while the excess water is being drained. The water sample (1-1 1) was aseptically taken from the well and pool waters into the previously sterilized screw capped flasks. The well water sample was taken from that tap, which continuously fills the 
pool. The pool water sample was taken from the middle of the pool. During the sampling, 12 people were present in the pool water. Samples were taken to the laboratory in a cooler bag and processed within $1 \mathrm{~h}$ of sampling.

\section{Determination of total cell count}

To determine the total cell count, a DAPI staining procedure was applied, as described by Máthé et al. [14]. For the investigations, $1 \mathrm{ml}$ of the pool water and $100 \mathrm{ml}$ of the well water were filtered.

\section{Cultivation}

To cultivate and isolate bacteria, 10\% R2A [15] and minimal synthetic media (prepared with own bath water) [13] with agar-agar or gellan gum were used. Also, $16 \mathrm{~g}$ agar-agar and $12 \mathrm{~g}$ gellan gum were used as a gelling reagent for $10 \% \mathrm{R} 2 \mathrm{~A}$ and minimal synthetic media.

In case of $10 \% \mathrm{R} 2 \mathrm{~A}$ with gellan gum, $0.3 \mathrm{~g} \mathrm{CaCl}_{2}$ and $0.6 \mathrm{~g} \mathrm{MgSO}_{4}$ were added to stabile gelling, but with agar-agar, no additional salts were needed. For minimal synthetic media with gellan gum, $0.5 \mathrm{~g} \mathrm{CaCl}_{2}$ and $0.75 \mathrm{~g} \mathrm{MgSO}_{4}$ or with agar-agar $0.32 \mathrm{~g} \mathrm{CaCl}_{2}$ were added for the same purpose.

During our studies, three different cultivation techniques were carried out. (1) The well and pool waters were directly spread to the $10 \% \mathrm{R} 2 \mathrm{~A}$ and the minimal synthetic media after a serial dilution of samples. Media were prepared both with agar-agar and gellan gum. After incubation $\left(9\right.$ days at $36^{\circ} \mathrm{C}$ and 16 days at $25^{\circ} \mathrm{C}$ ), CFU values were estimated. (2) For the enrichment of slowly growing bacteria, 50-50 $\mathrm{ml}$ water sample was added to $250-250 \mathrm{ml}$ liquid medium (10\% R2A and minimal synthetic media). After 3 weeks of incubation $\left(36^{\circ} \mathrm{C}\right)$, serial dilution was done from the enrichment cultures and 100-100 $\mu 1$ of each were spread to $10 \% \mathrm{R} 2 \mathrm{~A}$ and minimal media with agar-agar and gelrite. Plates were incubated at $36^{\circ} \mathrm{C}$ for $7-14$ days. (3) Polyurethane foam-based (PUF) traps were applied to enrich bacteria in 250-250 $\mathrm{ml}$ liquid medium (10\% R2A and minimal synthetic media). PUF blocks were sterilized in autoclave at $121^{\circ} \mathrm{C}$ for $20 \mathrm{~min}$ then soaked with hot agar-agar and gellan gum medium (10\% R2A and minimal synthetic media), then these PUF blocks were put into the appropriate liquid media. After the incubation $\left(3\right.$ weeks at $36^{\circ} \mathrm{C}$ and 3 weeks at $25^{\circ} \mathrm{C}$ ), the PUF blocks were taken out from the enrichment media and pressed several times with sterile mortal. The liquid from the PUF blocks was spread to $10 \% \mathrm{R} 2 \mathrm{~A}$ and minimal media after serial dilution. Plates were incubated at $36{ }^{\circ} \mathrm{C}$ for 4 days. 
About 170 bacterial strains were randomly isolated from the plates, then purified and maintained on 10\% R2A and minimal synthetic media with agar-agar or gelrite according to standard microbiological methods.

\section{DNA extraction from the bacterial strains}

DNA was extracted using glass beads for cell disruption. Cells were suspended in $100 \mu \mathrm{l}$ diethylpyrocarbonate treated water in a $600 \mu \mathrm{l}$ Eppendorf tube. Lysis of the cells was achieved by shaking for $2 \mathrm{~min}$ and $30 \mathrm{~Hz}$ by a MM301 mixer mill (Retsch, Haan, Germany) in the presence of $100 \mu 1$ sterile glass beads. The raw lysate was denaturated for $5 \mathrm{~min}$ at $98^{\circ} \mathrm{C}$ in a GeneAmp PCR System 2700 machine (Applied Biosystems). After centrifugation for $5 \mathrm{~min}$ at 10,000×g, the supernatant was used for the following PCR.

\section{PCR amplification of the 16S rRNA genes of bacterial strains}

The 16S rRNA gene fragments of bacterial DNA were amplified with universal primers 27F (5'-AGA GTT TGA TCM TGG CTC AG-3') and 1401R (5'-CGG TGT GTA CAA GAC CC-3'). The temperature protocol of the PCR was performed as described by Anda et al. [5] except the elongation time, which took $45 \mathrm{~s}$. The PCR mixture was the same, as previously described [5]. Amplification was carried out in a GeneAmp PCR System 2700 machine (Applied Biosystems). PCR products were checked by the same method, as previously described [5].

Amplified rDNA restriction analysis (ARDRA) to group the 170 bacterial strains

The amplified 16S rRNA gene fragments were digested using $B s u$ RI (GG

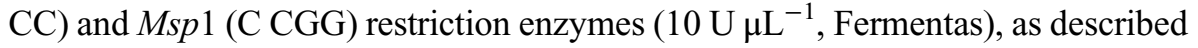
by Massol-Deya et al. [16]. The fragments were separated by the same method, as previously described [5]. The samples with identical restriction fragment patterns (for both restriction enzymes) were grouped together. Group representatives and ungrouped samples were chosen for $16 \mathrm{~S}$ rRNA gene sequence analysis to identify the selected bacterial strains.

$16 S$ rRNA gene sequence analysis

The partial 16S rRNA gene sequencing of the selected ARDRA representatives was performed using 27F (5'-AGA GTT TGA TCM TGG CTC AG-3') and 
1401R primers (5'-CGG TGT GTA CAA GAC CC-3'). Sequencing with Sanger method was carried out at LGC Ltd. (Berlin, Germany). The quality of chromatograms was checked manually with the help of the Chromas software (Technelysium Pty Ltd., Australia). Taxonomic relationships of the sequences were determined by EzTaxon database [17].

\section{Results and Discussion}

The temperature of the well originating water and the swimming pool water was the same $\left(36^{\circ} \mathrm{C}\right)$, the well water flows without any treatment to the swimming pool, and in the pool water, no disinfection process was done. Most probably, due to the anthropogenic effect, the quantity of cultivable heterotrophic bacteria was at least 10 fold higher in the pool $\left(1.095 \times 10^{4}\right.$ cells $\left.\mathrm{ml}^{-1}\right)$ as compared to the well $\left(6.34 \times 10^{2}\right.$ cells $\left.\mathrm{ml}^{-1}\right)$. The viable cell count was at least one to two orders of magnitude higher in the well $\left(6.705 \times 10^{5}\right.$ cells $\left.\mathrm{ml}^{-1}\right)$ and 10 fold higher in the pool water $\left(9.35 \times 10^{5}\right.$ cells $\left.\mathrm{ml}^{-1}\right)$, as compared to the plate counts.

Altogether, 170 bacterial strains (72 from the well and 98 from the pool water samples) were isolated and successfully maintained on different media. According to the $16 \mathrm{~S}$ rRNA gene sequence analysis, the members of Alphaproteobacteria provided the main group among the identified bacterial strains in the well (40 strains) and also in the pool water (71 strains) (Figure 1), in main phylogenetic lineages, the community of the well and pool waters was similar. The similarities of the sequenced bacterial strains to their closest relatives are listed in Table I. Representatives of Actinobacteria, Firmicutes, Beta- and Gammaproteobacteria, Deinococcus-Thermus, and Bacteroidetes were identified. The ratio of the Firmicutes phylum was higher in the well water (14 strains), than in the pool water (4 strains). Representatives of Deinococcus-Thermus (Deinococcus grandis) appeared only in the pool water.

The isolated bacterial species were all heterotrophic, except the facultative phototrophic Blastomonas natatoria [18].

Altogether, 19 bacterial genera were isolated from the well water and 22 from the pool water. Based on the literature data, many of the detected taxa are able to fix nitrogen, e.g., Pseudomonas azotiofingens [19], Rhizobium alkalisoli [20], Rhizobium straminoryzae [21], and also Hartmannibacter diazotrophicus [22], which show only low similarity to our isolates. In oligotrophic environments, nitrogen fixation often has a great importance due to the limited nitrogen source in these oligotrophic habitats.

The largest bacterial groups in the pool water belonged to the genera Tistrella and Chelatococcus. As the pool water comes from the well, some 




Figure 1. Phylogenetic distribution of cultivated bacterial strains from the well and pool waters of Gellért bath

bacterial genera (Bacillus, Ferrovibrio, Nocardioides, Porphyrobacter, Pseudomonas, and Tistrella) were detected at both sampling sites, but the overlap between the bacterial communities of the two sampling sites was little (Table I). Differences can originate from the fact that the original well water temperature is approximately $11^{\circ} \mathrm{C}$ higher than that of the pool water but also it assumes an anthropogenic effect in the pool water.

Many of the detected taxa are able to utilize amino acids as sole carbon source, e.g., Kinneretia asaccharophila [23], Acinetobacter baumanni [24], Fictibacillus nanhaiensis [25], Pannonibacter phragmitetus [26], Phenylobacterium falsum [27], Rhizobium alkalisoli [20], Porphyrobacter colymbi [28], and Pseudomonas knackmussii [29]. These microbes may also utilize the degradation products of proteins of the human epithelial surface or human perspiration can occur in the pool water. Based on the literature data, Dietzia cinnamea isolated from the pool water can also utilize testosterone [30].

The anthropogenic effect seems to be also confirmed by other facts: some bacterial species (Deinococcus grandis, Dietzia cinnamea, and Acinetobacter baumannii) isolated only from the pool water (Table I), based on the literature data they were also detected only from human samples till now. Originally, D. grandis was isolated from human epithelial surface [31], D. cinnamea from a perianal swab of a patient with bone marrow transplant [30]. A. baumannii is an 
Table I. Phylogenetic relatedness of ARDRA group representative and ungrouped bacterial strains. Strains with bold sign till now were described only from human sources. Notations in strain's signs: " $\mathrm{B}$ " originates from well water and " $\mathrm{M}$ " originates from the pool water. "Pu" means that the strain was isolated from polyurethane block. The small (diameter is less than $1 \mathrm{~mm}$ ) bacterial colonies were isolated by the help of a sterile toothpick marked with "F". "R" or "M" means that the strain was isolated from $10 \% \mathrm{R} 2 \mathrm{~A}$ or minimal synthetic medium. Strains isolated from a media solidified with agar-agar or gellan gum are marked with "A" or G". If a strain was isolated from the enrichment culture, it is marked with " $\mathrm{D}$ "

\begin{tabular}{|c|c|c|}
\hline $\begin{array}{l}\text { Selected representative strain (number of } \\
\text { all isolates in well } / \text { pool) }\end{array}$ & Closest relative (EzTaxon) & $\underset{\%}{\text { Similarity }}$ \\
\hline \multicolumn{3}{|l|}{ Alphaproteobacteria } \\
\hline PuMGM6 (0/1) & $\begin{array}{l}\text { Azospirillum rugosum IMMIB } \\
\text { AFH-6(T) }\end{array}$ & 97.77 \\
\hline RAM1 $(0 / 1)$ & Blastomonas natatoria DSM 3183(T) & 100.00 \\
\hline FDRGB2/b $(1 / 0)$ & $\begin{array}{l}\text { Brevundimonas vesicularis LMG } \\
2350(\mathrm{~T})\end{array}$ & 97.24 \\
\hline FDRGM8 $(0 / 1)$ & Brevundimonas viscosa $\mathrm{F} 3(\mathrm{~T})$ & 99.88 \\
\hline FDMGM4 (0/1) & Caenispirillum bisanense K92(T) & 99.61 \\
\hline $\begin{array}{l}\text { DRAM1, FDRAM6, FDRGM16, } \\
\text { FDRGM19, FDRGM6/a, FDRGM9, } \\
(0 / 22)\end{array}$ & Chelatococcus daeguensis K106(T) & 100.00 \\
\hline $\begin{array}{l}\text { DRAB2, FDMAM7, FDRAB2, } \\
\text { FDMGM9 (4/7) }\end{array}$ & Ferrovibrio denitrificans $\mathrm{Sp}-1(\mathrm{~T})$ & 100.00 \\
\hline $\begin{array}{l}\text { DMAB1, DMAB2, DMAB3, DMGB13 } \\
(30 / 0)\end{array}$ & $\begin{array}{l}\text { Hartmannibacter diazotrophicus } \\
\text { E19(T) }\end{array}$ & 93.93 \\
\hline DMGB7 (1/0) & $\begin{array}{l}\text { Methylobacterium goesingense } \\
\text { iEII3(T) }\end{array}$ & 99.39 \\
\hline RAM11 $(0 / 1)$ & Mycoplana dimorpha IAM 13154(T) & 96.83 \\
\hline DMGM8, FDMGM7 (0/3) & $\begin{array}{l}\text { Pannonibacter phragmitetus DSM } \\
14782(\mathrm{~T})\end{array}$ & 99.66 \\
\hline $\operatorname{MAB} 10(1 / 0)$ & Paracoccus siganidrum M26(T) & 98.19 \\
\hline DRAM15 (0/1) & Phenylobacterium falsum AC-49(T) & 98.40 \\
\hline MGM5 (1/2) & Porphyrobacter colymbi TPW-24(T) & 99.50 \\
\hline PuMAM10, PuMGM10 (0/4) & Rhizobium alkalisoli CCBAU 01393(T) & 97.23 \\
\hline DMAM1 $(0 / 1)$ & $\begin{array}{l}\text { Rhizobium straminoryzae } \\
\text { CC-LY845(T) }\end{array}$ & 99.90 \\
\hline FDRAB3 $(1 / 0)$ & Sphingopyxis indica DS15(T) & 98.99 \\
\hline $\begin{array}{l}\text { PuMGM1, FDMAM1, DMAM3, } \\
\text { DMAM14, PuMAM2 }(1 / 20)\end{array}$ & Tistrella mobilis TISTR 1108(T) & 99.64 \\
\hline \multicolumn{3}{|l|}{ Betaproteobacteria } \\
\hline PuMGB3 (1/0) & Caldimonas meghalayensis AK31(T) & 99.86 \\
\hline RAM12 (0/1) & $\begin{array}{l}\text { Kinneretia asaccharophilia } \\
\text { KIN192(T) }\end{array}$ & 99.75 \\
\hline MGB6, MGB2 (2/0) & Limnobacter thiooxidans CS-K2(T) & 99.87 \\
\hline \multicolumn{3}{|l|}{ Gammaproteobacteria } \\
\hline RAM9 (0/1) & $\begin{array}{l}\text { Acinetobacter baumannii ATCC } \\
\text { 19606(T) }\end{array}$ & 99.88 \\
\hline MAM9, MAM2 (0/3) & $\begin{array}{l}\text { Pseudomonas alcaligenes NBRC } \\
\text { 14159(T) }\end{array}$ & 99.76 \\
\hline
\end{tabular}


Table I. (cont.)

\begin{tabular}{|c|c|c|}
\hline $\begin{array}{l}\text { Selected representative strain (number of } \\
\text { all isolates in well/pool) }\end{array}$ & Closest relative (EzTaxon) & $\begin{array}{l}\text { Similarity } \\
\%\end{array}$ \\
\hline FDRAB19 $(1 / 0)$ & Pseudomonas azotifigens $6 \mathrm{H} 33 \mathrm{~b}(\mathrm{~T})$ & 97.91 \\
\hline MAM12 (0/1) & $\begin{array}{l}\text { Pseudomonas balearica } \\
\text { SP1402(T) }\end{array}$ & 99.64 \\
\hline RGM5 (0/1) & Pseudomonas knackmussii $\mathrm{B} 13(\mathrm{~T})$ & 97.57 \\
\hline \multicolumn{3}{|l|}{ Firmicutes } \\
\hline FDRAB14, FDRGB11, FDRGM2 (6/3) & Bacillus licheniformis ATCC 14580(T) & 99.62 \\
\hline $\begin{array}{l}\text { FDRGB12, FDRGB17, } \\
\text { FDRAB12 }(7 / 0)\end{array}$ & Brevibacillus choshinensis DSM 8552(T) & 97.93 \\
\hline RGM1 (0/1) & Fictibacillus nanhaiensis JSM 082006(T) & 100 \\
\hline DRAB1 $(1 / 0)$ & $\begin{array}{l}\text { Paenibacillus lautus NRRL } \\
\text { NRS-666(T) }\end{array}$ & 99.00 \\
\hline \multicolumn{3}{|l|}{ Actinobacteria } \\
\hline RAB11 (1/0) & $\begin{array}{l}\text { Brachybacterium paraconglomeratum } \\
\text { LMG }\end{array}$ & 99.75 \\
\hline MGB4 (1/0) & $\begin{array}{l}\text { Corynebacterium humireducens } \\
\text { MFC } 5(\mathrm{~T})\end{array}$ & 99.00 \\
\hline RAM10 $(0 / 1)$ & Dietzia cinnamea IMMIB RIV-399(T) & 99.62 \\
\hline $\begin{array}{l}\text { DRAM3, MGM2, MGB5, FDMGM1, } \\
\text { FDRAB7, FDRAM8/b }(10 / 10)\end{array}$ & Micrococcus luteus NCTC 2665(T) & 100.00 \\
\hline RAM13 (0/1) & Nocardioides daphniae D287(T) & 97.35 \\
\hline DMGB6 $(1 / 0)$ & Nocardioides furvisabuli SBS-26(T) & 98.50 \\
\hline \multicolumn{3}{|l|}{ Bacteroidetes } \\
\hline PuMAB9, PuMAM9 (1/1) & Sphingobacterium composti 24M24(T) & 99.47 \\
\hline \multicolumn{3}{|l|}{ Deinococcus-Thermus } \\
\hline $\operatorname{RAM20}(0 / 3)$ & Deinococcus grandis DSM 3963(T) & 98.49 \\
\hline
\end{tabular}

opportunistic bacterial pathogen, primarily associated with hospital-acquired infections, e.g., pneumonia, wound infections, and urinary tract infections [32]. Bacillus licheniformis (which is a common bacterium in soils) detected both in the well and pool waters can also be opportunistic pathogen, can cause sepsis [33], aortic valve endocarditis [34], and food poisoning [35]. Pseudomonas alcaligenes detected only in the pool water was initially described as opportunistic pathogen, which causes endocarditis [36], although since then it has been detected from numerous environmental samples. One of the closest relative of strain FDRGB2b is the type strain of Brevundimonas vesicularis (97.24\%), which is also a facultative pathogen that causes endocarditis [37], peritonitis [38], and septic arthritis [39]. In our case, FDRGB2b appeared only in the well water, and therefore its human origin is excluded. Moreover, it must also be stated that these taxa could be cultivated only after enrichment, 
their real number is most probably very low in these waters. The most dominant member of the pool water was Tistrella mobilis, previously detected in deep sea of the Middle Atlantic Ridge [40] and in wastewater [41]. This bacterium produces an antimicrobial agent (didemnin) [42], which can be responsible for the dominant appearance of Tistrella mobilis also in the pool water of Gellért bath. The effect of this agent of the bacterial community structure needs further studies in our case; the antimicrobial effect of our strains was not yet tested.

Bacterial species previously detected in the swimming pool water (Blastomonas natatoria [43], Pseudomonas alcaligenes [44], and Porphyrobacter colymbi [45]) were also identified in the pool water of Gellért bath.

The dominant member of the well water belonged to a new taxon, according to the 16S rDNA sequences; its similarity to Hartmannibacter diazotrophicus as closest relative was only $93.93 \%$. This bacterium occurred only in the well water.

The entire microbial community of the thermal water of pools and wells has been rarely studied. It has been mainly investigated by a hygienic view in the previous research studies. The whole bacterial community of an indoor warmwater $\left(33^{\circ} \mathrm{C}\right)$ therapy pool in an American Midwestern regional hospital has been studied with molecular methods [46]. During the February sampling, the dominant members of the pool water belonged to the Gammaproteobacteria and Bacteroidetes/Chlorobi and Firmicutes taxa. Our samples were investigated only by cultivation and it is hard to make comparisons with molecular results. Even so when we do it very carefully, the results show that in the pool of Gellert bath, the Alphaproteobacteria taxon was dominant (74.4\%) and the members of Actinobacteria were also abundant $(12.2 \%)$. These taxa were detected in the American therapy pool though in lower quantity as well. During the second sampling in the American hospital pool in August, the members of the Sphingomonadaceae family (Alphaproteobacteria) and the Mycobacterium genus (Actinobacteria) were dominant, Beta- and Gamma-proteobacteria, Actinobacteria, Bacillus, and Clostridia (Firmicutes) were also represented. In the pool water of the Gellért bath, these taxa were also isolated except the class Clostridia. Contrary to our sample, representatives of Deinococcus-Thermus phylum were not detected in the American therapy pool. Differences can also come from the different applied methods, though overlaps are obvious. Another swimming pool water of a college was studied with cultivation methods, where the dominance of the Firmicutes phylum was detected, and the members of Actinobacteria were identified as well [47].

Members of the Alphaproteobacteria class were also detected in Tunisian springs [1] in Yellowstone National Park [48] or in Diana/Hygieia spring (Hungary) [4], but less dominantly. Members of Beta- and Gamma-proteobacteria occurred frequently in thermal springs [1, 4], and in the well of Gellért bath, they were not 
isolated in high number $(4.2 \%$ and $1.4 \%)$. The second largest isolated group was related to Firmicutes (18.4\%) phylum in the well water of Gellért bath.

From the well water, representatives of species Caldimonas meghalayensis and Ferrovibrio denitrificans were also identified. Both taxa were described from aquatic habitats, the former from a spring in India [49], while the latter one from a Russian spring [50]. In addition, members of the genera Sphingobacterium and Sphingopyxis were detected in a sulfurous well (called "Matty") in Harkány (Hungary) [2].

\section{Conclusions}

The thermal water of the well and pool waters have diverse bacterial communities. Our aim was not to reveal the hygienic state of the thermal bath; it is done regularly by the operators. At the same time, it must be stated that the anthropogenic effect has a great influence on the autochthon microbial community of the studied waters. On the other hand, even with enrichments, only a few facultative pathogenic microbes could be revealed, which underlines that the hygienic state of the studied water bodies is obviously good. Interestingly from the well water, novel taxa could be isolated, one is far from each known bacterial species. It underlines that oligotrophic environments have a hidden cultivable diversity that is worthy to study.

\section{Conflict of Interest}

There is no conflict of interest present connected to the work.

\section{References}

1. Sayeh, R., Birrien, J. L., Alain, K., Barbier, G., Hamdi, M., Prieur, D.: Microbial diversity in Tunisian geothermal springs as detected by molecular and culture-based approaches. Extremophiles 14, 501-514 (2010).

2. Borsodi, A., Miseta, R., Palatinszky, M., Makk, J., Márialigeti, K.: Spatial and temporal changes of bacterial communities inhabiting the well waters of Harkány spa. Acta Microbiol Immunol Hung 60, 329-343 (2013).

3. Miseta, R., Palatinszky, M., Makk, J., Márialigeti, K., Borsodi, A. K.: Phylogenetic diversity of bacterial communities associated with sulfurous karstic well waters of a Hungarian spa. Geomicrobiol J 29, 101-113 (2012).

4. Anda, D., Bükki, G., Krett, G., Makk, J., Márialigeti, K., Erőss, A., Mádl-Szőnyi, J., Borsodi, A. K.: Diversity and morphological structure of bacterial communities inhabiting the Diana-Hygieia thermal spring (Budapest, Hungary). Acta Microbiol Immunol Hung 61, 329-346 (2014). 
5. Anda, D., Makk, J., Krett, G., Jurecska, L., Márialigeti, K., Mádl-Szőnyi, J., Borsodi, A. K.: Thermophilic prokaryotic communities inhabiting the biofilm and well water of a thermal karst system located in Budapest (Hungary). Extremophiles 19, 1-11 (2015).

6. Goldscheider, N., Mádl-Szőnyi, J., Erőss, A., Schill, E.: Review: Thermal water resources in carbonate rock aquifers. Hydrogeol J 18, 1303-1318 (2010).

7. Erőss, A., Csoma, E. A., Mádl-Szőnyi, J.: The effects of mixed hydrothermal and meteoric fluids on karst reservoir development. Buda Thermal Karst, Hungary. In Sasowsky, I. D., Feazel, C. T., Mylorie, J. E., Palmer, A. N., Palmer, M. V. (eds): Karst from Recent to Reservoirs. Special Publication 14, Karst Waters Institute, Leesburg, VA, 2008, pp. 57-63.

8. Poindexter, J. S.: Oligotrophy: Fast and famine existence. Adv Microbiol Ecol 5, 63-89 (1981).

9. Amann, R. I., Ludwig, W., Schleifer, K. H.: Phylogenetic identification and in situ detection of individual microbial cells without cultivation. Microbiol Rev 59, 143-169 (1995).

10. Davis, K. E. R., Joseph, S. J., Janssen, P. H.: Effects of growth medium, inoculum size, and incubation time on culturability and isolation of soil bacteria. Appl Environ Microbiol 71, 826-834 (2004).

11. Kamagata, Y., Tamaki, H.: Cultivation of uncultured fastidious microbes. Microbes Environ 20, 85-91 (2005).

12. Yasumoto-Hirose, M., Nishijima, M., Ngirchechol, M. K., Kanoh, K., Shizuri, Y., Miki, $\mathrm{W}$.: Isolation of marine bacteria by in situ culture on media-supplemented polyurethane foam. Mar Biotechnol (NY) 8, 227-237 (2006).

13. Kéki, Z., Gérbner, K., Bogus, V., Márialigeti, K., Tóth, E.: Application of special oligotrophic media for cultivation of bacterial communities originated from ultrapure water. Acta Microbiol Immunol Hung 60, 345-357 (2013).

14. Máthé, I., Borsodi, A. K., Tóth, E. M., Felföldi, T., Jurecska, L., Krett, G., Kelemen, Z., Elekes, E., Barkács, K., Márialigeti, K.: Vertical physico-chemical gradients with distinct microbial communities in the hypersaline and heliothermal Lake Ursu (Sovata, Romania). Extremophiles 18, 501-514 (2014).

15. Reasoner, D. J., Geldreich, E. E.: A new medium for the enumeration and subculture of bacteria from potable water. Appl Environ Microbiol 49, 1-7 (1985).

16. Massol-Deya, A. A., Odelson, D. A., Hickey, R. F., Tiedje, J. M.: Bacterial community fingerprinting of amplified 16S and 16-23S ribosomal DNA sequences and Restriction Endonuclease Analysis (ARDRA). Kluwer Academic Publishers, Dordrecht, 1995, pp. 3.3.2:1-3.3.2:8.

17. Kim, O. S., Cho, Y. J., Lee, K., Yoon, S. H., Kim, M., Na, H., Park, S. C., Jeon, Y. S., Lee, J. H., Yi, H., Won, S., Chun, J.: Introducing EzTaxon-e: A prokaryotic 16S rRNA Gene sequence database with phylotypes that represent uncultured species. Int J Syst Evol Microbiol 62, 716-721 (2012).

18. Hiraishi, A., Kuraishi, H., Kawahara, K.: Emendation of the description of Blastomonas natatoria (Sly 1985) Sly and Cahill 1997 as an aerobic photosynthetic bacterium and reclassification of Erythromonas ursincola Yurkov et al. 1997 as Blastomonas ursincola comb. nov. Int J Syst Evol Microbiol 50, 1113-1118 (2000).

19. Hatayama, K., Kawai, S., Shoun, H., Ueda, Y., Nakamura, A.: Pseudomonas azotifigens sp. nov., a novel nitrogen-fixing bacterium isolated from a compost pile. Int J Syst Evol Microbiol 55, 1539-1544 (2005). 
20. Lu, Y. L., Chen, W. F., Han, L. L., Wang, E. T., Chen, W. X.: Rhizobium alkalisoli sp. nov., isolated from Caragana intermedia growing in saline-alkaline soils in the north of China. Int J Syst Evol Microbiol 59, 3006-3011 (2009).

21. Lin, Y. S., Hsu, Y. H., Liu, Y. C., Hung, M. H., Hameed, A., Lai, W. A., Yen, W. S., Young, C. C.: Rhizobium straminoryzae sp. nov., isolated from the surface of rice straw. Int J Syst Evol Microbiol 64, 2962-2968 (2014).

22. Suarez, C., Ratering, S., Geissler-Plaum, R., Schnell, S.: Hartmannibacter diazotrophicus gen. nov., sp. nov., a phosphate-solubilizing and nitrogen-fixing alphaproteobacterium isolated from the rhizosphere of a natural salt-meadow plant. Int J Syst Evol Microbiol 64, 3160-3167 (2014).

23. Gomila, M., Pinhassi, J., Falsen, E., Moore, E. R. B., Lalucat, J.: Kinneretia asaccharophila gen. nov., sp. nov., isolated from a freshwater lake, a member of the Rubrivivax branch of the family Comamonadaceae. Int J Syst Evol Microbiol 60, 809-814 (2009).

24. Bouvet, P. J. M., Grimont, P. A. D.: Taxonomy of the genus Acinetobacter with the recognition of Acinetobacter baumannii sp. nov. Acinetobacter haemolyticus sp. nov. Acinetobacter johnsonii sp. nov. and Acinetobacter junii sp. nov. and Emended Descriptions of Acinetobacter calcoaceticus and Acinetobacter lwofii. Int J Syst Bacteriol 36, 228240 (1986).

25. Chen, Y. G., Zhang, L., Zhang, Y. Q., He, J. W., Klenk, H. P., Tang, S. K., Zhang, Y. X., Li, W.-J.: Bacillus nanhaiensis sp. nov., isolated from an oyster. Int J Syst Bacteriol 61, 888-893 (2010).

26. Borsodi, A. K., Micsinai, A., Kovács, G., Tóth, E., Schumann, P., Kovács, A. L., Böddi, B., Márialigeti, K.: Pannonibacter phragmitetus gen. nov., sp. nov., a novel alkalitolerant bacterium isolated from decomposing reed rhizomes in a Hungarian soda lake. Int J Syst Evol Microbiol 53, 555-561 (2003).

27. Tiago, I., Mendes, V., Pires, C., Morais, P. V., Veríssimo, A.: Phenylobacterium falsum sp. nov., an Alphaproteobacterium isolated from a nonsaline alkaline groundwater, and emended description of the genus Phenylobacterium. Syst Appl Microbiol 28, 295302 (2005).

28. Furuhata, K., Edagawa, A., Miyamoto, H., Kawakami, Y., Fukuyama, M.: Porphyrobacter colymbi sp. nov. isolated from swimming pool water in Tokyo, Japan. J Gen Appl Microbiol 59, 245-250 (2013).

29. Stolz, A., Busse, H. J., Kämpfer, P.: Pseudomonas knackmussii sp. nov. Int J Syst Evol Microbiol 57, 572-576 (2007).

30. Yassin, A. F., Hupfer, H., Schaal, K. P.: Dietzia cinnamea sp. nov., a novel species isolated from a perianal swab of a patient with bone marrow transplant. Int J Syst Evol Microbiol 56, 641-645 (2006).

31. The NIH HMP Working Group: The NIH Human Microbiome Project. Genome Research. 19, 2317-2323 (2009).

32. Choi, H. C., Lee, J. S., Lee, Y. C., Park, T. I., Lee, J. C.: Acinetobacter baumannii invades epithelial cells and outer membrane protein-A mediates interactioms with epithelial cells. BMC Microbiol 8, 1-11 (2008).

33. Haydushka, I. A., Markova, N., Kirina, V., Atanassova, M.: Recurrent sepsis due to Bacillus licheniformis. J Glob Infect Dis 4, 82-83 (2012).

34. Santini, F., Borghetti, V., Amalfitano, G., Mazzucco, A.: Bacillus licheniformis prosthetic aortic valve endocarditis. J Clin Microbiol 33, 3070-3073 (1995). 
35. Mikkola, R., Kolari, M., Andersson, M. A., Helin, J., Salkinoja-Salonen, M. S.: Toxic lactonic lipopeptide from food poisoning isolates of Bacillus licheniformis. Eur J Biochem 267, 4068-4074 (2003).

36. Valenstein, P., Bardy, G. H., Cox, C. C., Zwadyk, P.: Pseudomonas alcaligenes endocarditis. Am J Clin Pathol 79, 245-247 (1983).

37. Yang, M. L., Chen, Y. H., Chen, T. C., Lin, W. R., Lin, C. Y., Lu, P. L.: Case report: Infective endocarditis caused by Brevundimonas vesicularis. BMC Infect Dis 6, 1-5 (2006).

38. Choi, W., Lee, C., Kim, A., Choi, J. W., Seo, S., Lee, J., Pío, H., Kwon, Y. J.: CAPD peritonitis due to Brevundimonas vesicularis. Pediatr Med Chir 26, 510-512 (2006).

39. Sofer, Y., Zmira, S., Amir, J.: Brevundimonas vesicularis septic arthritis in an immunocompetent child. Eur J Pediatr 166, 77-78 (2007).

40. Cui, Z., Shao, Z.: Predominant strains of polycyclic aromatic hydrocarbon-degrading consortia from deep sea of the Middle Atlantic Ridge. Wei Sheng Wu Xue Bao 49, 902-909 (2009).

41. Shi, B. H., Arunpairojana, V., Palakawong, S., Yokota, A.: Tistrella mobilis gen. nov., sp. nov., a novel polyhydroxyalkanoate-producing bacterium belonging to $\alpha$-Proteobacteria. J Gen Appl Microbiol 48, 335-343 (2002).

42. Xu, Y., Kersten, R. D., Nam, S.-J., Lu, L., Al-Suwailem, A. M., Zheng, H., Fenical, W., Dorrestein, P. C., Moore, B. S., Qian, P.-Y.: Bacterial biosynthesis and maturation of the didemnin anti-cancer agents. J Am Chem Soc 134, 8625-8632. (2012).

43. Sly, L. I., Hargreaves, M. H.: Two unusual budding bacteria isolated from a swimming pool. J Appl Bacteriol 56, 479-486 (1984).

44. Hugh, R., Ikari, P.: The proposed neotype strain of Pseudomonas alcaligenes Monlas 1928. Int Bull Bacteriol Nomenclature Taxonomy 14, 103-107 (1964).

45. Furuhata, K., Edagawa, A., Miyamoto, H., Kawakami, Y., Fukuyama, M.: Porphyrobacter colymbi sp. nov. isolated from swimming pool water in Tokyo, Japan. J Gen Appl Microbiol 59, 245-250 (2013).

46. Angenent, L. T., Scott, T. K., Allison, St. A., Norman, R. P., Hernandez, M. T.: Molecular identification of potential pathogens in water and air of a hospital therapy pool. Proc Natl Acad Sci U S A 102, 4860-4865 (2005).

47. Robinton, E. D., Mood, E. W., Elliot, L. R.: A study of bacterial flora in swimming pool water treated with high-free residual chlorine. Am J Public Health 47, 1101-1109 (1957).

48. Johnson, D. B., Okibe, N., Roberto, F. F.: Novel thermo-acidophilic bacteria isolated from geothermal sites in Yellowstone National Park: Physiological and phylogenetic characteristics. Arch Microbiol 180, 60-68 (2003).

49. Rakshak, K., Ravinder, K., Nupur, V., Srinivas, T. N. R., Kumar, P. A.: Caldimonas meghalayensis sp. nov., a novel thermophilic betaproteobacterium isolated from a hot spring of Meghalaya in northeast India. Antonie Van Leeuwenhoek 104, 1217-1225 (2013).

50. Sorokina, A. Y., Chernousova, E. Y., Dubinina, G. A.: Ferrovibrio denitrificans gen. nov., sp. nov., a novel neutrophilic facultative anaerobic Fe(II)-oxidizing bacterium. FEMS Microbiol Lett 335, 19-25 (2012). 